\title{
Individual Level Performance Analysis of Block Technology Team Members of Agricultural Technology Management Agency in Assam, India
}

\author{
Chittaranjan Deka $^{1 *}$, P. Mishra ${ }^{2}$, H. Sarmah ${ }^{2}$ \\ ${ }^{1}$ KVK, Barpeta, Assam, India \\ ${ }^{2}$ Department of Extension Education, CA/AAU, Jorhat-13, Assam, India \\ *Corresponding author
}

\section{A B S T R A C T}

\section{Keywords}

ATMA, Block Technology Team (BTT), Functions/ Activities, Role and performance

\section{Article Info}

Accepted: 18 May 2020 Available Online: 10 June 2020
The ATMA model is a central government initiative in the year 2005-06, which was designed to be implemented by each state at the district level.. In 2005 the Government of India expanded the ATMA model to 252 districts under SSEPER, and then in 2007 to all districts of the country. At district level the ATMA would be gradually more responsible for all the technology dissemination activities. It would have linkage with all the line departments, research organisations, non-governmental organisations and agencies associated with agricultural development in the district. As the ATMA programme is under operation for the last thirteen years in Assam, the researchable questions may arise that to how and what extent the extension personnel (Members of ATMA Block Technology Team) from respective district performed their role to accomplish the functions/activities of ATMA. Keeping in view, a research study was carried out with the objectives i.e 1. To assess role performance of BTT members of ATMA 2. To find out relationship between the independent variables and the level of role performance of BTT members. 3. To study the Contributory effects of selected independent variables on the role performance of BTT members. A multistage purposive cum random sampling method was followed for selection of the respondents of the study. The findings of the level of role performance of the BTT members revealed that 88.10 per cent of the respondents had low to medium level of performance. Only 11.90 per cent of them were found with high level of role performance. The value of coefficient of multiple regression $\left(\mathrm{R}^{2}\right)$ being 0.621 indicated that the independent variables jointly contributed 62.10 per cent towards the role performance of BTT members. The $\mathrm{F}$ value $\left(\mathrm{F}=3.541^{* *}\right)$ was also found to be significant. This indicates the significant effectiveness of these variables in explaining the role performance of BTT members when all of them were functioning jointly.

\section{Introduction}

The shrinking size of the average land holding of an Indian farmer has held back agricultural productivity and there is not much that can be done about this. But there are other areas which can be worked upon. As the State of the Indian Agricultural Report points out: "To enhance productivity, easy and reliable access to inputs such as quality seeds, fertilizers, 
pesticides, access to suitable technology tailored for specific needs, the presence of support infrastructure and innovative marketing systems to aggregate and market the output from large number of small holdings efficiently." In this connection there is an increasing need for stronger intermediaries that can facilitate information access for diverse smallholder farmers. Further progress in poverty and hunger reduction crucially depends on the increased productivity and profitability of these farmers, which in turn depends on the successful delivery of agricultural extension. Recent global food price increases and high levels of inflation have provided an opportunity to increase farmers' profitability. However, to realize the benefit of higher prices, farmers need to access a wider range of information, related not only to production technologies but also to postharvest processes, access to remunerative markets, price information, and business development (Sulaiman and van den Ban, 2003). This information could be integrated with services that support the use of the information. For example, technology information needs to be supported with information about reliable sources for that technology, and where credit can be accessed. In India, the role of agricultural extension in improving agricultural growth is today being recognized with increasing investment. India's $10^{\text {th }}$ and $11^{\text {th }}$ five-year plans emphasize agricultural extension as a key to increasing agricultural growth by reducing the yield gap in farmer fields, and therefore stress the need to strengthen agricultural extension in India (Planning Commission, 2001, 2005, 2006).

Assam's agriculture has yet to experience modernization in a real sense and is lagging behind. With implications to food security, per capita food grain production has declined in past five decades (UNDP, 2004). On the other hand, although productivity of crops increased marginally, still these are much lower in comparison to highly productive regions.

The T\&V System was effective in disseminating Green Revolution technology, especially in the high potential, irrigated areas, but it had little effect on the productivity and incomes among farmers in rain fed areas (Swanson and Mathur, 2003; Singh et al., 2005c). In mid-1990s, the Govt. of India and the World Bank began exploring new approaches to extension that would address these system problems and constraints resulting in new, decentralized extension approach, which would focus more on diversification, thereby that making it more market-oriented and increasing farm income and rural employment. The central institutional innovation that emerged to address these system problems was the Agricultural Technology Management Agency or "ATMA" model that was introduced at the district level.

At district level the ATMA would be gradually more responsible for all the technology dissemination activities at the district level. It would have linkage with all the line departments, research organisations, non-governmental organisations and agencies associated with agricultural development in the district. Research and Extension units within the districts such as Zonal Research Station (ZRS) or Sub-stations, Krishi Vigyan Kendras (KVKs) and the key line Departments of Agriculture, Animal Husbandry, Horticulture and Fisheries etc. would become constituent members of ATMA. Each Research-Extension (R-E) unit would retain its institutional identity and affiliation but programmes and procedures concerning district-wise R-E activities would be determined by ATMA Governing Board to be implemented by its ATMA Management Committee (AMC). As a society, it would be 
able to receive and expend funds, entering into contracts and agreements and maintaining revolving accounts that can be used to collect fees and thereby recovering operating cost.

As the ATMA programme is under operation for the last thirteen years, the researchable questions may arise that to how and what extent the extension personnel (Members of ATMA Block Technology Team) from respective district performed their role to accomplish the functions/activities of ATMA. Keeping in view, a research study was carried out with the objectives i.e 1. To assess role performance of members ATMA Block Technology Team (BTT) 2. To find out relationship between the independent variables and the level of role performance of BTT members. 3. To study the Contributory effects of selected independent variables on the role performance of BTT members.

\section{Materials and Methods}

The present study was conducted in two districts namely Kokrajhar and Bongaigaon of Assam during the year 2014-15. A multistage purposive cum random sampling method was followed for selection of the respondents of the study. From two selected district 60 per cent of BTT members were selected randomly. The sixty per cent of BTT members accounts 42 nos. of respondents from two districts. To measure the level of role performance as perceived by the extension personnel of ATMA Block Technology Team (BTT), a standardized index was developed following the procedure followed by Sharma et al., (2012). The procedure followed for development of the index is described in the following paragraphs.

Sixty five statements, expressing the role items of extension personnel of BTT members in the revitalized extension system were collected from available literature, ATMA guideline 2010, researchers and experts in the field of extension. These items were edited on the basis of criteria suggested by Thurstone (1946), Likert (1932) and Edward (1957). Finally, a total of 52 items of BTT were retained respectively. The selected 52 items of members of BTT were sent to 60 judges through self-addressed envelope. The judges were requested to evaluate these role statements on a three point continuum, viz., 'Most Relevant' (MR), 'Relevant'( $R)$ and 'Less Relevant' (LR). A score of 3, 2 and 1 were given for $\mathrm{MR}, \mathrm{R}$ and $\mathrm{LR}$, respectively. Thus, the relevancy data furnished by 50 judges were taken into consideration for arriving at the selection of role items for the index. Finally 33 items of members of BTT with the largest ' $t$ ' values were selected for the performance index.

Before measuring 'performance' of a particular role item, a filter question (Did you perform?) was asked to check whether a particular role item was performed or not. The role items were then administered for evaluating the level of performance. The answers to the question "What level?" was administered on five point continuum with categories ranging from "most frequently performed" to "never performed" through "frequently performed", "sometime performed" and "rarely performed" and the scores assigned were 4, 3, 2, 1 and 0 respectively. The total score of each respondent was calculated by summing the scores obtained by him/her against each role item. The scores on each of the items were worked out for all the respondents separately.

The total score for a given role items obtainable by a respondent ranged from 0 to 132. The higher score indicates that respondent had higher level of role performance and vice-versa. 
Based on the mean ( $\bar{X})$ and standard deviation (S.D.) of the obtained scores, respondents were classified into three categories as shown below:

\begin{tabular}{|c|c|}
\hline Category & Score range \\
\hline $\begin{array}{c}\text { Low level of } \\
\text { performance }\end{array}$ & Up to $\overline{\mathrm{X}}-1$ S.D. \\
\hline $\begin{array}{c}\text { Medium level of } \\
\text { performance }\end{array}$ & $\overline{\mathrm{X}}-1$ S.D. to $\overline{\mathrm{X}}+1$ S.D. \\
\hline $\begin{array}{c}\text { High level of } \\
\text { performance }\end{array}$ & Above $\overline{\mathrm{X}}+1$ S.D. \\
\hline
\end{tabular}

Ranks were given to each role items based on the weighted mean score to find out the level of role performance. The highest rank of the role item in the rank order means the highest perceived level of role performance.

Karl Pearson's coefficient of correlation was used to examine the relationship of the selected personal and psychological variables viz., age, job experience, job satisfaction, achievement motivation, role conflict, motivational profile, job values cherished, job involvement, attitude towards extension work, organizational climate, job stress and leadership ability with the level of role performance of the BTT members. On the other hand to study the contributory effects of selected independent variables in explaining the variation in each of the dependent variable, multiple linear regression analysis was employed.

The primary data in the present study were collected directly from the respondents with the help of the structured schedule through personal interview method. The interview schedule was taken to each of the respondent's viz., members of BTT by the investigator. After establishing rapport, questions contained in the schedule were explained to each respondent and the responses received were recorded by the investigator. The data collected in the study were coded, classified, tabulated and analyzed in order to make the findings meaningful. Various descriptive and inferential statistical methods were used to analyze the data in the present study.

\section{Results and Discussion}

Level of role performance as perceived by the respondents (BTT members)

It is evident from the data presented in the Table 1(a) that majority $(71.43 \%)$ of the respondents had medium level of role performance followed by 16.67 per cent respondents had low level of role performance. The least number of BTT members i.e. 11.90 per cent had high level of role performance. The value of coefficient of variation (15.52) indicates that the respondents were more homogenous with respect to their level of role performance. A pie diagram showing the distribution of respondents according to their level of role performance was drawn and presented in Fig.1.

Performance of different role items by the respondents (BTT Members)

Table 2(a) reveals that the highest rank was occupied by the role "Cooperation in preparation of block action plan" with a weighted mean score of 3.30 The role 'Coordinate the implementation of extension programme detailed in the BAP' stood second in the rank order with a weighted mean score of 3.21 followed by the three roles "Facilitate formation of FIGs/FOs at the block level", "Organizing exhibition, kissan mela, field day, exposure visit" and "Helping farmers' group in maintaining proper register and records" placed in the same rank third with a weighted mean score of 3.04. The other roles occupied their ranked according to their values of weighted mean scores. 
Cooperation in preparation of block action plan by the BTT members is most important to carry out the different cafeteria of activities of ATMA in schedule time and to address the resource poor farmers. "Coordinating the implementation of extension programmes detailed in the BAP" by the members helps to carry out the different activities expediently in time. "Facilitate the farmers towards formation of FIGs/FOs" help to conduct demonstration and other entrepreneurial activity." "Organizing exhibition, kisan mela, field day, exposure visit" plays a vital role for capacity building and to create awareness among the farmers. "Helping farmers' group in maintaining proper register and records" is important in calculating cost benefit ration of different technology which help to measure the successfulness of any extension programme. These fairly justified the role numbers 3, 4 and the three roles i.e. 5, 10 and 21 being in the rank 1, 2 and 3, respectively.

Six major roles that were "Exploring new areas of farming (Value added products) having present and future prospect", "Identification and prioritization of needs and interest of the farmers", "Provide information regarding marketing of produce to the farmers" "Documentation and publication of success stories of farmers", "Mobilizing fund needed for documentation and publication of success stories" and "Mobilizing fund needed for capacity building programme for farmers" placed in the later rank viz., thirteenth, eighteenth, nineteenth, twenty one, twenty three and twenty six respectively. This perhaps ignored to some extent by the BTT members.

\section{Relationship between the independent variables and the level of role performance of BTT members}

It is evident from data presented in the Table 3(a) that the level of role performance of BTT members had positive and significant correlation with job satisfaction $\left(\mathrm{r}=0.466^{* *}\right)$, achievement motivation $\left(\mathrm{r}=0.401^{* *}\right)$, motivational profile $\left(\mathrm{r}=0.446^{* *}\right)$, job values cherished $(\mathrm{r}=0.427 * *)$, attitude towards extension work $(\mathrm{r}=0.547 * *)$, organizational climate $\left(\mathrm{r}=0.594^{* *}\right)$ and leadership ability $\left(\mathrm{r}=0.611^{* *}\right)$ at 0.01 level of probability while the variable job experience $\left(r=0.316^{*}\right)$ had positive and significant correlation at 0.05 level of probability.

It can be seen that while attitude towards extension work, organizational climate and leadership ability had moderately strong relationship with the level of role performance of the BTT members, the variables viz., job experience, job satisfaction, achievement motivation, motivational profile and job values cherished showed relatively weaker relationship with the level of role performance of the BTT members.

Table 3(a) also reveals that the level of role performance of BTT members had negative and significant correlation with role conflict $(\mathrm{r}=-0.523 * *)$ and job stress $(\mathrm{r}=-0.532 * *)$. However, age and job involvement were found to have no significant relationship with the level of role performance of BTT members.

The variables like 'Organisational climate' and 'Leadership ability' were also positively correlated with the level of role performance of the BTT members involved in ATMA. The degree of happiness with one's job and the total environment of an organization in terms of physical facilities, sense of team work and common purpose, a strong commitment to interpersonal communication and managerial empowerment are related with the performance level. Success of any rural development programme has been attributable mostly to the leadership roles, as it develops awareness among the villagers in 
understanding the problems and the interrelation and interaction between community participation, technical knowledge and environmental impact. So, the BTT members involved in ATMA were more aware about their leadership ability. The result of the present study conforms to the findings of Halakatti et al., (1977), Talukdar (1984), Reddy (1986), Sundaraswamy (1987) and Hallkatti (1991), Singh (1985), Shadur et al., (1999). Wong and Wong (2000) and Manjunath and Shashidahra (2011).

Table.1(a) Distribution of respondents (BTT members) according to their level of role performance

\begin{tabular}{|l|c|c|c|c|c|c|}
\hline Category & $\begin{array}{c}\text { Score } \\
\text { range }\end{array}$ & Frequency & $\begin{array}{c}\text { Percentage } \\
(\boldsymbol{\%})\end{array}$ & Mean & S.D & C.V \\
\hline Low & 15 to 67 & 7 & 16.67 & 79.38 & 12.32 & 15.52 \\
\hline Moderate & 68 to 92 & 30 & 71.43 & & & \\
\hline High & 93 to 120 & 5 & 11.90 & & & \\
\hline
\end{tabular}

Table.2(a) Performance of different role items by the respondents (BTT Members)

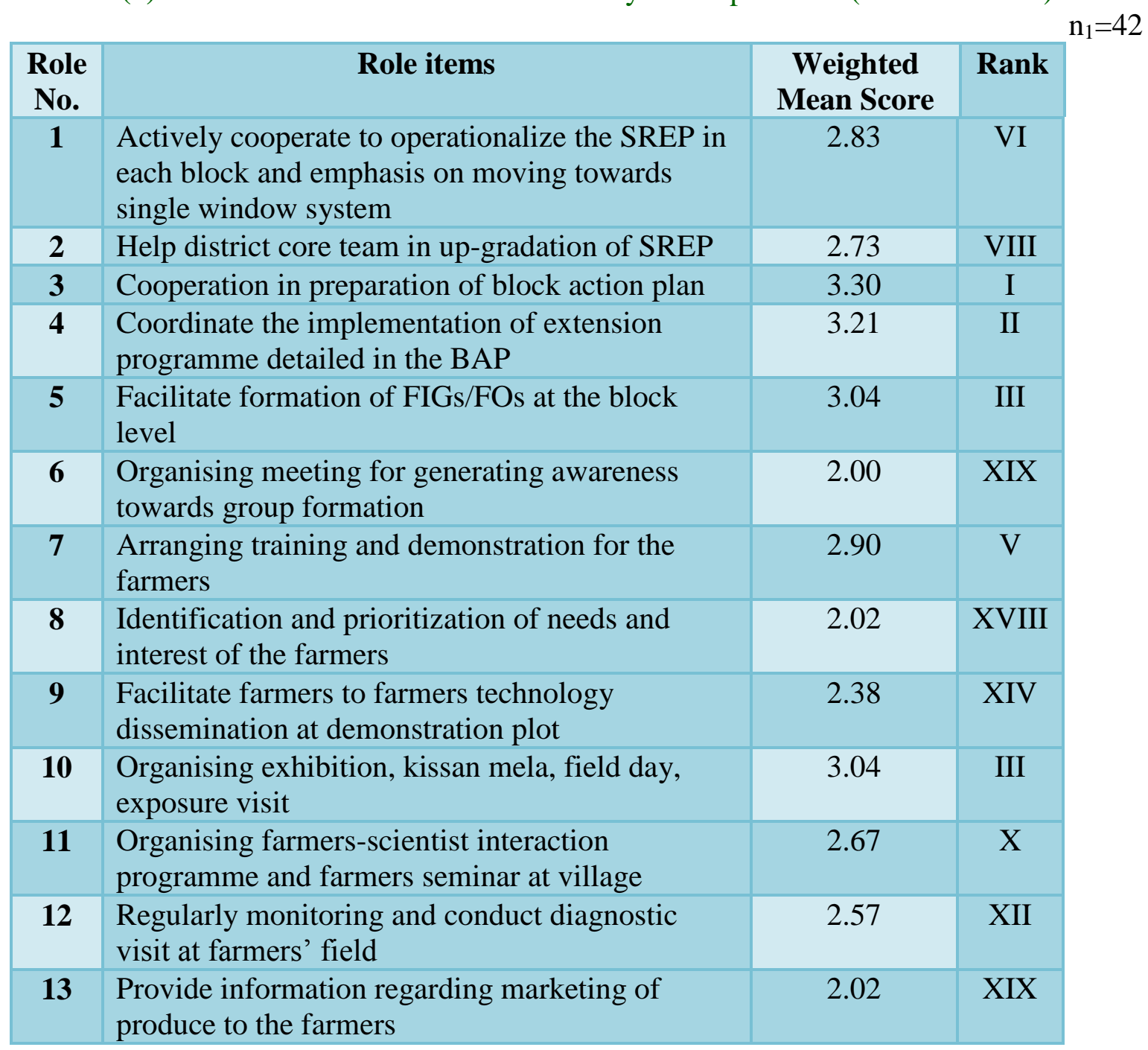




\begin{tabular}{|c|c|c|c|}
\hline 14 & $\begin{array}{l}\text { Help in developing linkage among farmers, } \\
\text { lending institutions, input dealers and NGOs }\end{array}$ & 2.70 & IX \\
\hline 15 & $\begin{array}{l}\text { Addressing gender concerns by mobilizing farm } \\
\text { women into group }\end{array}$ & 2.97 & IV \\
\hline 16 & $\begin{array}{l}\text { Developing and publishing resource materials } \\
\text { (Folder, Extension Bulletin, Training Mannual) } \\
\text { for farmers in local language }\end{array}$ & 2.04 & XVII \\
\hline 17 & $\begin{array}{l}\text { Developing technology packages in electronic } \\
\text { form }\end{array}$ & 1.30 & $\mathrm{XXV}$ \\
\hline 18 & Developing training modules for farmers & 1.38 & XXIV \\
\hline 19 & $\begin{array}{l}\text { Exploring new areas of farming (Value added } \\
\text { products) having present and future prospect }\end{array}$ & 2.54 & XIII \\
\hline 20 & $\begin{array}{l}\text { Helping farmers' groups in maintaining } \\
\text { sustainability and leadership }\end{array}$ & 2.76 & VIII \\
\hline 21 & $\begin{array}{l}\text { Helping farmers' group in maintaining proper } \\
\text { register and records }\end{array}$ & 3.04 & III \\
\hline 22 & $\begin{array}{l}\text { Guiding farmers in accessing information } \\
\text { through ICT linkage }\end{array}$ & 2.61 & $\mathrm{XI}$ \\
\hline 23 & $\begin{array}{l}\text { Coordinating assessment, refinement, validation } \\
\text { and adoption of front line technologies with } \\
\text { KVKs and other local research centres }\end{array}$ & 2.19 & $\mathrm{XV}$ \\
\hline 24 & $\begin{array}{l}\text { Documentation and publication of success stories } \\
\text { of farmers }\end{array}$ & 1.83 & XXI \\
\hline 25 & $\begin{array}{l}\text { Keeping inventory of all the farmers' } \\
\text { organization and beneficiaries }\end{array}$ & 2.09 & XVI \\
\hline 26 & $\begin{array}{l}\text { Keeping inventory of the capacity building } \\
\text { programmes including participating farmers and } \\
\text { resource persons }\end{array}$ & 1.97 & $\mathrm{XX}$ \\
\hline 27 & $\begin{array}{l}\text { Maintaining proper record and account for } \\
\text { activities carried out }\end{array}$ & 2.38 & XIV \\
\hline 28 & $\begin{array}{l}\text { Provisioning rewards and incentives for } \\
\text { successful farmers/groups }\end{array}$ & 2.97 & IV \\
\hline 29 & $\begin{array}{l}\text { Provisioning seed money/revolving fund for } \\
\text { operational zing farmers' group }\end{array}$ & 2.61 & $\mathrm{XI}$ \\
\hline 30 & $\begin{array}{l}\text { Compiling report on utilization of fund and the } \\
\text { physical progress of work }\end{array}$ & 2.38 & XIV \\
\hline 31 & $\begin{array}{l}\text { Mobilizing fund needed for capacity building } \\
\text { programme for farmers }\end{array}$ & 1.14 & XXVI \\
\hline 32 & $\begin{array}{l}\text { Mobilizing fund needed for functioning of farm } \\
\text { school }\end{array}$ & 1.80 & XXII \\
\hline 33 & $\begin{array}{l}\text { Mobilizing fund needed for documentation and } \\
\text { publication of success stories }\end{array}$ & 1.57 & XXIII \\
\hline
\end{tabular}


Table.3(a) Relationship between the independent variables and the level of role performance of BTT members

$\mathrm{n}_{1}=42$

\begin{tabular}{|c|c|c|c|}
\hline SI. No. & Independent variables & 'r' value & 't' value \\
\hline 1 & Age & 0.045 & 0.284 \\
\hline 2 & Job experience & $0.316^{*}$ & 2.106 \\
\hline 3 & Job satisfaction & $0.466 * *$ & 3.331 \\
\hline 4 & Achievement motivation & $0.401 * *$ & 2.768 \\
\hline 5 & Role Conflict & $-0.523 * *$ & 3.880 \\
\hline 6 & Motivational profile & $0.446 * *$ & 3.151 \\
\hline 7 & Job values cherished & $0.427 * *$ & 2.986 \\
\hline 8 & Job involvement & 0.221 & 1.433 \\
\hline 9 & $\begin{array}{l}\text { Attitude towards extension } \\
\text { work }\end{array}$ & $0.547 * *$ & 4.133 \\
\hline 10 & Organisational climate & $0.594 * *$ & 4.669 \\
\hline 11 & Job stress & $-0.532 * *$ & 3.973 \\
\hline 12 & Leadership ability & $0.611 * *$ & 4.881 \\
\hline
\end{tabular}

**Significant at 0.01 level probability

*Significant at 0.05 level probability

Table.3(b) Contributory effects of selected independent variables on the role performance of BTT members

\begin{tabular}{|c|c|c|c|}
\hline $\begin{array}{l}\text { Sl. } \\
\text { No. }\end{array}$ & \multicolumn{2}{|l|}{ Variables } & t value \\
\hline 1 & Age & 0.188 & -0.534 \\
\hline 2 & Job experience & 0.166 & 0.710 \\
\hline 3 & Job satisfaction & $0.120 * *$ & 0.531 \\
\hline 4 & \multicolumn{2}{|l|}{ Achievement motivation } & 0.659 \\
\hline 5 & \multicolumn{2}{|l|}{ Role Conflict } & 0.818 \\
\hline 6 & \multicolumn{2}{|l|}{ Motivational profile } & 0.559 \\
\hline 7 & Job values cherished & $0.019 *$ & 0.021 \\
\hline 8 & \multicolumn{2}{|l|}{ Job involvement } & 0.165 \\
\hline 9 & \multicolumn{2}{|l|}{ Attitude towards extension work } & 0.023 \\
\hline 10 & \multicolumn{2}{|l|}{ Organisational climate } & 0.523 \\
\hline 11 & \multicolumn{2}{|l|}{ Job stress } & 0.097 \\
\hline \multirow[t]{2}{*}{12} & Leadership ability & $0.024 *$ & 0.066 \\
\hline & \multicolumn{2}{|l|}{$\mathrm{R}^{2}=0.621$} & $\mathrm{~F}$ value $=3.541 * *$ \\
\hline
\end{tabular}

*Significant at 0.05 level of probability

**Significant at 0.01 level of probability 
Fig.1 Level of role performance of BTT Members

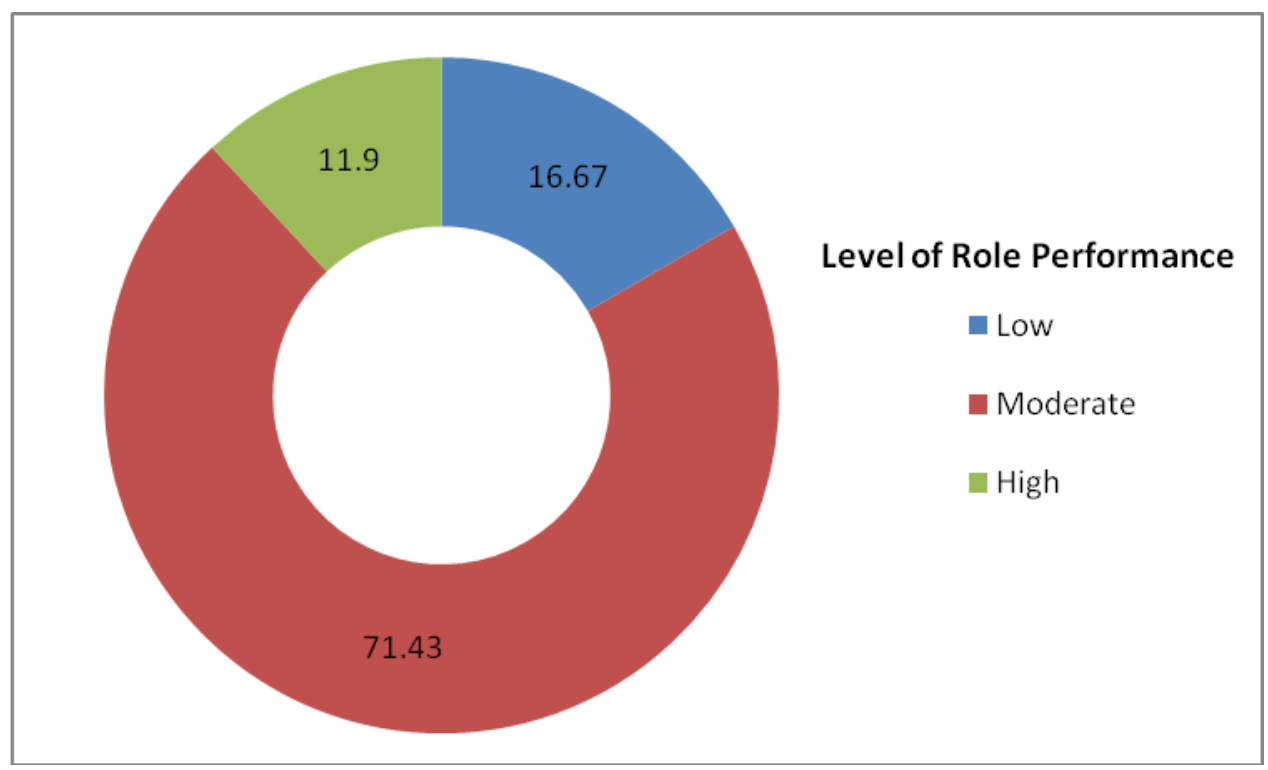

Contributory effects of selected independent variables on the level of role performance of BTT members

It is evident from the data presented in the Table 3(b) that job satisfaction $(b=0.120 * *)$, achievement motivation $(b=0.139 * *)$, motivational profile $(b=0.118 * *)$, job values cherished $\left(b=0.019^{*}\right)$ attitude towards extension work $\left(b=0.025^{*}\right)$, organizational climate $\left(b=0.131^{* *}\right)$ and leadership ability $\left(b=0.024^{*}\right)$ had positive and significant contribution towards explaining the variation in the level of role performance of BTT members.

It is observed from the table that variables like role conflict $(b=-0.187 * *)$ and job stress $(b=-0.027 *)$ were found to have negative and significant contribution towards the role performance of BTT members.

The value of coefficient of multiple regression $\left(\mathrm{R}^{2}\right)$ being 0.621 indicated that the independent variables jointly contributed 62.10 per cent towards the role performance of BTT members. The F value $\left(\mathrm{F}=3.541^{* *}\right)$ was also found to be significant. This indicates the significant effectiveness of these variables in explaining the role performance of BTT members when all of them were functioning jointly.

It is concluded that the findings of the level of role performance of the BTT members revealed that 88.10 per cent of the respondents had low to medium level of performance. Only 11.90 per cent of them were found with high level of role performance. An effective extension management approach for organizational performance should seek to pin point the gaps in performance of their assigned roles and try to reduce them as far as realistic. Higher level of role performance is likely to impact positively on employees' and organization's well-being. Care should also be taken to improve the organisational climate to increase the job satisfaction and achievement motivation. The findings of correlation analysis between the independent variables and the level of role performance of the extension personnel, indicated that the variables job satisfaction, achievement motivation, motivational profile, job values cherished, attitude towards extension work, 
organizational climate, leadership ability and job experience were the important variables influencing the level of role performance of BTT members. A highly significant and positive correlation of these variables with the level of performance indicated that the BTT members with higher job satisfaction and achievement motivation, more favourable motivational profile, highly respect their job values, highly favourable attitude towards extension work, more favourable organizational climate and high leadership ability were likely to influence the level of role performance to great extent. Where these attributes are at lower level in the extension personnel, appropriate management strategies may be adopted to modify their behaviour for increased level of performance of their roles. The value of coefficient of multiple regression $\left(R^{2}\right)$ being 0.621 indicated that the independent variables viz; job satisfaction, achievement motivation, motivational profile, job value cherished, attitude towards extension work, organizational climate, leadership ability jointly contributed 62.10 per cent towards the role performance of BTT members. The $\mathrm{F}$ value $\left(\mathrm{F}=3.541^{*} *\right)$ was also found to be significant..Therefore, there is possibility for policy makers, extension planners; higher level administrators, etc to manipulate these crucial factors in order to bring about desirable changes in level of performance of their roles.

\section{Acknowledgement}

No words would ever sustain the appreciation for eager involvement and unceasing encouragement at every stage of investigation extended by Dr. P. Mishra, Professor, Department of Extension Education, Assam Agricultural University, Jorhat-13 and the Chairman of the Advisory committee. It was his zeal and enthusiasm, which made it possible for the author to complete the work. I must confess that it has been a rare privilege for me to work under his guidance. I take this opportunity to express my deep sense of gratitude to Dr. N. Bordoloi, Prof. and Head, Dept of EE, FA, AAU, Jorhat and member of my Advisory Committee for his efficient guidance and constant encouragement to me during the course of my study and research. The author offers his heartfelt reverence to his beloved Mother, wife and Daughter, for their affectionate, love, blessing, inspiration, help and support for which he has reached that height of academic life.

\section{References}

Edwards, A.L. (1957). Techniques of Attitude Scale Construction. Appleton century crafts, Inc., New York.

Halakatti, S.V.; Sundaraswamy, B. and Nagnur, S. (1977). Job performance of Agril. Assistants. Agril. Extn. Review, pp. 28-30.

Halkatti, S.V. (1991). A study on job performance and job attitude of Agril. Assistants in $\mathrm{T}$ and $\mathrm{V}$ system of Karnataka, Ph.D thesis, UAS, Dharwad.

India, Ministry of Agriculture (2000). Policy framework for agricultural extension. New Delhi: Ministry of Agriculture, Department of Agriculture and Cooperation, Extension Division. $<$ http://agricoop.nic.in/ policy_framework.htm>. Accessed June $18,2015$.

Likert, R. (1932). A technique for measurement of Attitudes. Arch. Psychology. No.140.

Manjunath, L. and Shashidahra, K.K. (2011). Determinates of scientific productivity of agricultural scientists. Indian Res. J. Ext. Edn. 11(1): 7-12.

Planning Commission (2001). Approach paper to the tenth five year plan (20022007). New Delhi: Yojana Bhavan.

Planning Commission (2005). Midterm appraisal of the 10th five year plan 
(2002-

2007).<http://planningcommission.nic.i n/plans/mta/midterm/midtermapp.html > . Accessed July 14, 2015.

Planning Commission (2006). Towards faster and more inclusive growth: An approach to the $11^{\text {th }}$ five year plan (2007-2012). New Delhi: Yojana Bhavan.

Reddy, R.T. (1986). A study on selected personal, characteristics and organizational factors influencing the productivity of VEOs in $\mathrm{T}$ and $\mathrm{V}$ system of Andhra Pradesh. Ph.D thesis, UAS, Bangalore.

Revised ATMA Guideline (2010). Guidelines for modified "Support to State Extension Programmes for Extension Reforms" scheme, 2010. New Delhi: Ministry of Agriculture, Department of Agriculture and Cooperation.

Shadur, M.A.; Kienzle, R. and Rodwell, J.J. (1999). The relationship between organizational climate and employee perceptions of involvement: The importance of support. Group Orgn. Mngt. 24(4): 479-503.

Singh, J.P.; Swanson, B.E. and Singh K.M. (2005). Developing a Decentralized, Market-Driven Extension System in India: The ATMA Model. Good Practice Paper prepared for the World Bank, Washington DC. Swanson, B.E. and P.N. Mathur.

Singh, S. (1985). A study of school climate, leadership behavior and moral development of the heads of elementary and secondary schools. (Doctoral dissertation Unpublished). Punjab University, India.

Sulaiman, R. and van den Ban, A.W. (2003). Funding and delivering agricultural extension in India. J. Intern. Agril. Extn. Edn. 10(1): 21-30.

Sundaraswamy, B. (1987). A study on need achievement and job performance of Assistant Agricultural Officers in Karnataka State, Ph.D thesis, TNAU, Coimbatore

Swanson, B.E. and Mathur, P.N. (2003). Review of the Agricultural Extension System in India, unpublished report.

Shamna, A.; Gowda, B.K.; Gowda, S.N.S. and Suresha, S.V. (2012). A Scale to Measure Performance of Village Resource Centres on Farming Activities in Karnataka. Indian Res. J. Extn. Edn. 12(1): 39-43.

Thurstone, L.L. (1946). The measurement of Attitude. American J. Sociol. 52: 39-50.

Talukdar, R.K. (1984). Productivity of Agril. Development officers in Haryana: A Factor Analysis Study. Ph.D Thesis, HAU, Hissar.

UNDP (2004). Economy of Assam. < https://en.wikipedia.org/wiki/ Economy_of_Assam>. Accessed, July 29, 2016.

Wong, S.T. and Wong, S.T. (2000). Source choice perception and sustainable rural water supply development : A case study of Ban Thadindam, Laplauri, Thauland. Water Int. 25(4): 586-594.

\section{How to cite this article:}

Chittaranjan Deka, P. Mishra and Sarmah, H. 2020. Individual Level Performance Analysis of Block Technology Team Members of Agricultural Technology Management Agency in Assam, India. Int.J.Curr.Microbiol.App.Sci. 9(06): 2000-2010.

doi: https://doi.org/10.20546/ijcmas.2020.906.246 